\title{
Comparative study of gross tonnage of wooden purse seiners of Ratnagiri, Maharashtra
}

\author{
SIDDHESH S. DESAI, MAKARAND T. SHARANGDHAR AND ASHISH S. MOHITE
}

\begin{abstract}
For the wooden purse seiners having capacity ranging from 25 to 50 tons, the overall length ranged from 11.58 to $19.1 \mathrm{~m}$, breadth at midship 2.28 to $7.90 \mathrm{~m}$, depth of vessel 1.52 to $2.95 \mathrm{~m}$, length of freeboard 0.6258 to $1.2147 \mathrm{~m}$, draught 0.8941 to $1.5705 \mathrm{~m}$, length of keel 8.81 to $14.28 \mathrm{~m}$ and horse power of engine between 94 to $198 \mathrm{hp}$. Whereas, for wooden purse seiners having capacity ranging from 50 to 100 tons, overall length ranged from 11.39 to $17.9 \mathrm{~m}$, breadth at midship 3.4 to $7.90 \mathrm{~m}$, depth of vessel 1.58 to $3.4 \mathrm{~m}$, length of freeboard 0.6505 to $1.4 \mathrm{~m}$, draught 0.9294 to $1.5882 \mathrm{~m}$, length of keel 8.16 to 13.68 $\mathrm{m}$ and horse power of engine between 99.24 to $151 \mathrm{hp}$. All wooden purse seiners were fitted with Ashok Leyland make six cylinder inboard diesel engines.
\end{abstract}

KEY WORDS : Purse-seining, Wooden purse seiners, Gross tonnage, Technical specifications

How to cite this Article : Desai, Siddhesh S., Sharangdhar, Makarand T. and Mohite, Ashish S. (2016). Comparative study of gross tonnage of wooden purse seiners of Ratnagiri, Maharashtra. Engg. \& Tech. in India, 7 (2) : 84-86; DOI : 10.15740/HAS/ETI/7.2/ 84-86. 